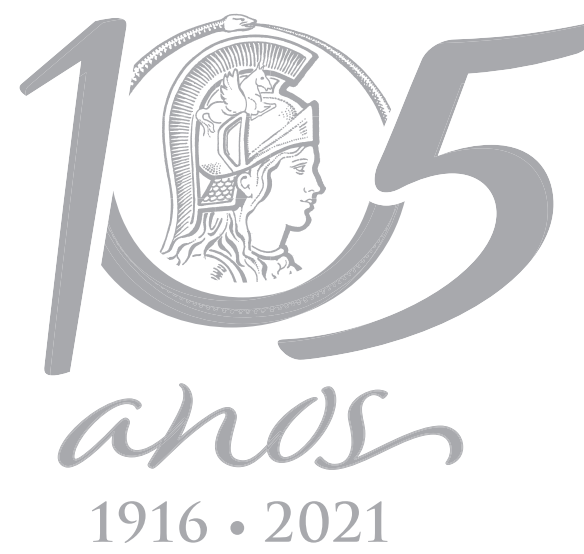

\title{
Acid sulfate soils from Antarctica: genesis and properties along a climatic gradient
}

\author{
RAFAEL G. SIQUEIRA, DAVI V. LOPES, JOSÉ JOÃO L.L. DE SOUZA, CARLOS ERNESTO \\ G.R. SCHAEFER, CAROLINE D. SOUZA, FÁBIO S.DE OLIVEIRA \& ELPÍDIO INÁCIO \\ FERNANDES FILHO
}

\begin{abstract}
Sulfurization is a pedogenic process that involves pyrite oxidation and strong soil acidification, accounting for the formation of acid sulfate soils. In Antarctica, acid sulfate soils are related to specific parent materials, such as sulfide-bearing andesites in Maritime Antarctica and pyritized sedimentary rocks in James Ross Archipelago. The hypothesis is that the acid sulfate soils of these regions vary according with a climate gradient. The reviewing of current data showed that the acid sulfate soils of warmer and wetter Maritime Antarctica have a greater weathering degree, higher acidity, leaching, phosphorus adsorption capacity, structural development, and well-crystallized iron oxides and kaolinite formation. On the other hand, the sulfurization at the drier region of James Ross Archipelago is counterbalanced by the semiaridity, resulting in lower acidity and higher base contents combined with little morphological and mineralogical evolution besides presence of weatherable minerals in the clay fraction. The sulfurization process interplays with other pedogenic processes, such as the phosphatization in Maritime Antarctica and salinization in James Ross Archipelago. Higher temperatures and soil moisture enhance the pedogenesis, showing that even the Antarctic sulfate soils, which originated from specific parent materials, have their development and characteristics controlled by a clear climatic gradient.
\end{abstract}

Key words: Chemical weathering, jarosite, pedogenesis, pyrite, soil acidity, sulfurization.

\section{INTRODUCTION}

Sulfurization is a microbiologically mediated process that involves the oxidation of sulfide minerals, such as pyrite, accumulation of sulfoxyanions, and precipitation of hydroxysulfates, such as jarosite and schwertmannite, with occasional Feoxyhydroxides (Bigham \& Nordstrom 2000). The process also generates extreme acidification due to sulfuric acid production, enhancing the chemical weathering of the affected soils and substrates (Dent 1986, Tatur et al. 1993).

The sulfurization products are known as acid sulfate soils, characterized by $\mathrm{pH}$ value of
3.5 or less (Soil Survey Staff 2014), besides acid drainage formation and yellowish colors due to the jarosite (Dent \& Pons 1995). According to Dent (1986), a soil containing pyrite is a potential acid sulfate soil if the potential acidity is greater than the acid-neutralizing capacity of the soil provided by carbonates, exchangeable bases, and easily weatherable silicates. The acid sulfate soils present morphological, chemical, and mineralogical changes in relation to their parent material (Tatur et al. 1993). These soils occur worldwide where sulfidic materials are exposed to $\mathrm{O}_{2}$-rich conditions through drainage driven by sea- or base-level change, or human 
activity (Dent \& Pons 1995, Öborn \& Berggren 1995, Bigham \& Nordstrom 2000).

In Antarctica, acid sulfate soils are closely related to the occurrence of pyritized parent materials (Balks et al. 2013, Simas et al. 2015). Pedologic surveys involving these soils in the Antarctic ice-free areas are scarce, even more when compared with well-known soils, such as saline, cryoturbated or ornithogenic soils (Campbell \& Claridge 1987, Bockheim \& Ugolini 1990). However, contributions for the last 20 years in the Antarctic Peninsula region have increased the knowledge about the sulfate soils, mainly in the adjacent islands from Maritime Antarctica and James Ross Archipelago (Schaefer et al. 2015, Simas et al. 2015).

Maritime Antarctica has a comparatively mild humid climate, which, when combined with sulfide minerals oxidation, allows higher soil development (Simas et al. 2008). The sulfate soils in James Ross Archipelago also present high degree of development due to sulfurization, incompatible with the current drier and colder climatic conditions (Schaefer et al. 2015). Overall, the sulfurization generates Antarctic sulfate soils with great mineralogical transformations, rapid chemical reactions, high leaching rates, and clay accumulation (Simas et al. 2006).

The parent material controls the acid sulfate soil formation due to the kinetics and spontaneous nature of the sulfurization and was pointed out as the main acid sulfate soils formation factor of Antarctica (Francelino et al. 2011, Simas et al. 2015). We hypothesized that, just as a parent material, climate is also a major soil factor affecting sulfurization. The present study aims to evaluate the characteristics and variability of acid sulfate soils in a well-defined climatic gradient across the Maritime Antarctica and James Ross Archipelago to understand the interplay between the sulfurization and the Antarctic Peninsula climate diversity.

\section{MATERIALS AND METHODS}

\section{Study areas}

\section{Maritime Antarctica}

The Maritime Antarctica (MA), in the Northwestern Antarctic Peninsula, is the northernmost region of Antarctica, localized between the latitudes $61^{\circ}$ and $63^{\circ} 25^{\prime} \mathrm{S}$. It includes the South Shetland Islands (Fig. 1), which have the Livingston and King George islands as the largest ice-free areas (Simas et al. 2015). The retreat of the MA glaciers started between 8 and 6 Ky BP, with a climatic optimum occurring between 4 and 3 Ky ago (Ingólfsson \& Hjort 2002).

The MA have a sub-Antarctic cold, moist, maritime climate with mean annual precipitation ranging from 350 to $800 \mathrm{~mm}$ (Blumel \& Eitel 1989). The mean annual air temperature is about $-2^{\circ} \mathrm{C}$, with mean summer temperatures above $0^{\circ} \mathrm{C}$ for up to 4 months (Navas et al. 2008). The thermal amplitude in summer days activates the freezing-thawing cycles of the widespread cryoturbated soils (Michel et al. 2012, Almeida et al. 2014).

Large moss carpets are common, indicating sufficient water availability and landscape stability, driving the formation of thick organic soils (Michel et al. 2006, Rodrigues et al. 2019). Lichens and algae occur along with bryophytes and two vascular plants: the grass Deschampsia antarctica and the herb Colobanthus quitensis (Poeking et al. 2009, Ferrari et al. 2020). Guano input from penguins and other seabirds is important in coastal areas and significantly influences soil development (Rodrigues et al. 2021).

The main soils are the Gelisols, mainly at altitudes above $80 \mathrm{~m}$ a.s.l., where permafrost is continuous (López-Martínez et al. 2012). From 20 to $80 \mathrm{~m}$ a.s.l. the permafrost is discontinuous, and Gelisols usually occur associated with 


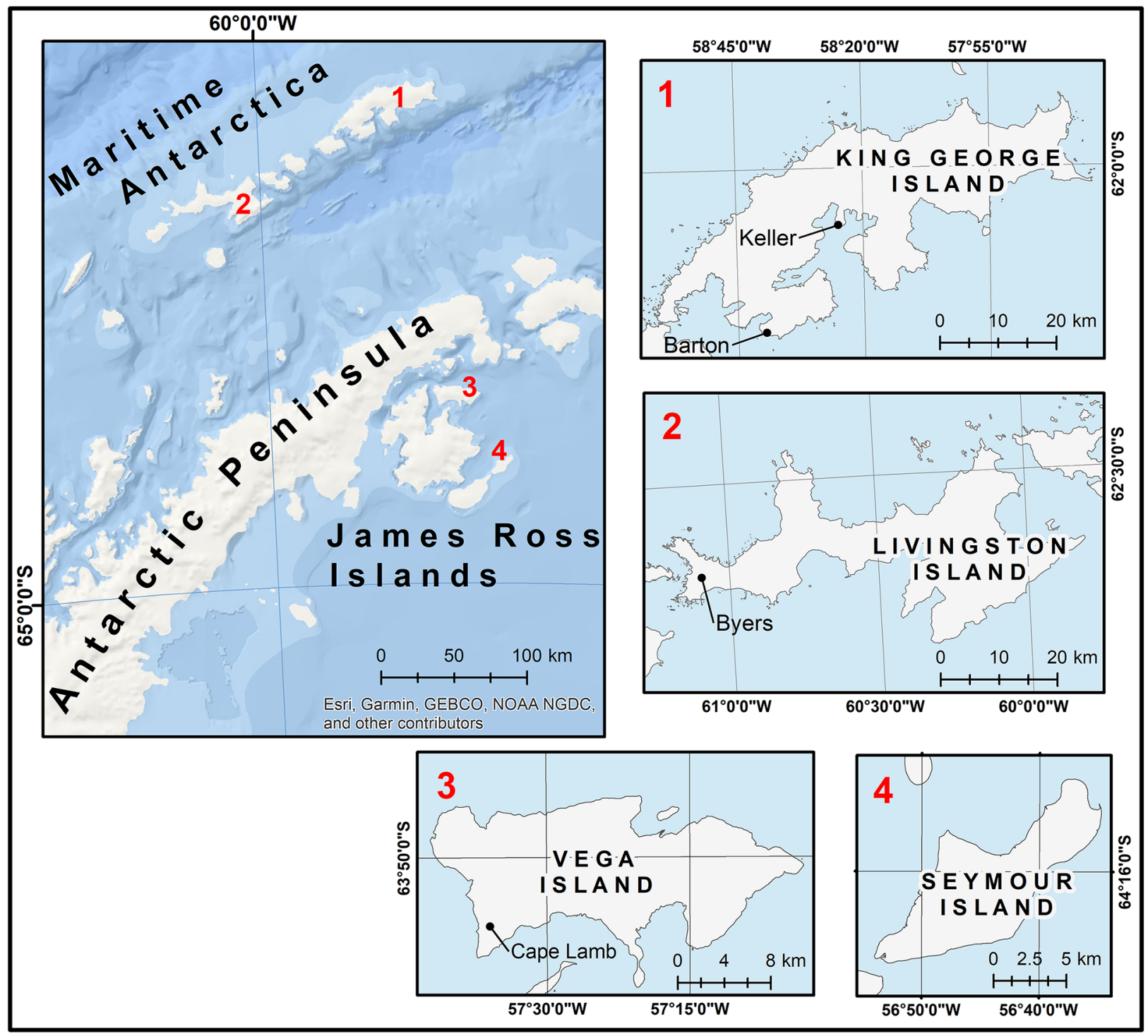

Figure 1. Antarctic Peninsula and islands with acid sulfate soils from Maritime Antarctica and James Ross Archipelago.

Entisols and Inceptisols. Below 20-30 m a.s.l. permafrost is absent or occasional (sporadic), and most soils key out as Entisols (Simas et al. 2015).

Soils in MA form predominantly from volcanic substrates, mainly Upper Cretaceous to Paleogene basaltic rocks of the Antarctic Peninsula arc (Francelino et al. 2011). Marine sedimentary rocks, plutonic bodies, and pyroclasts occur to a lesser extent. Moraines, solifluction, and fluvioglacial deposits are directly associated with the main surface landforms (López-Martínez et al. 2012). Sulfidebearing andesites also occur with local veins of pyrite, which, when exposed to the surface, contrast from the surrounding basaltic materials by the yellowish colors of the acid sulfate soils originated from them (Fig. 2)

\section{James Ross Archipelago}

James Ross Archipelago (JRA), in Weddell Sea (Eastern side of Antarctic Peninsula), is localized 

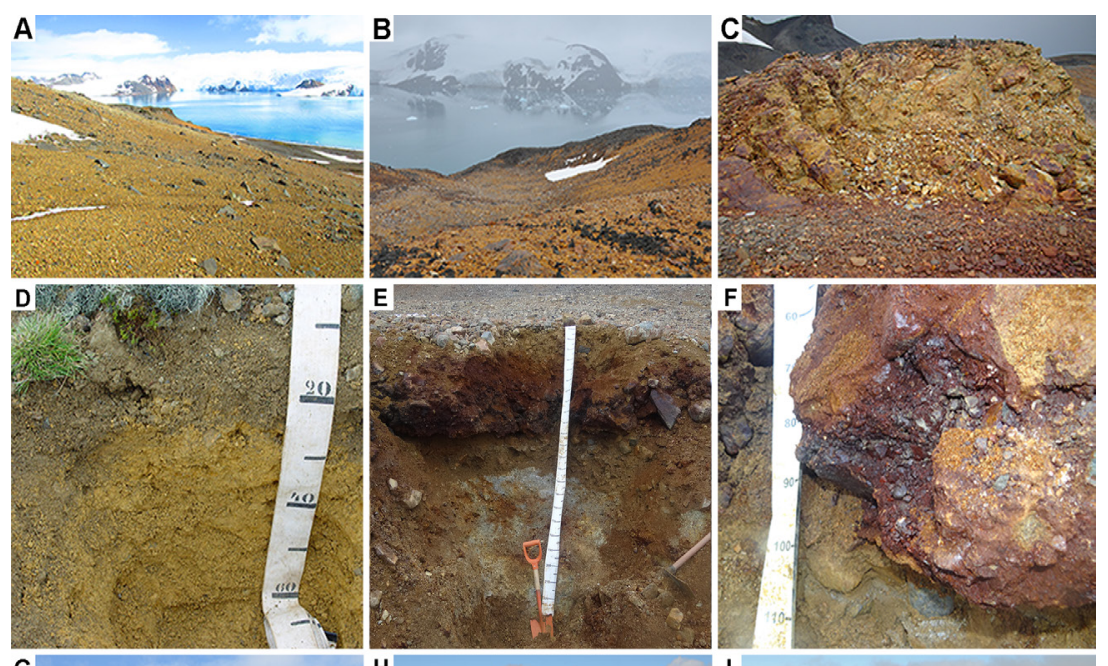

Figure 2. Landscapes, geology and acid sulfate soils of Maritime Antarctica and James Ross Archipelago. MA: a) Sulfate affected landscape in Barton, b) Sulfate affected landscape in Keller, c) Sulfide-bearing andesite outcrop,
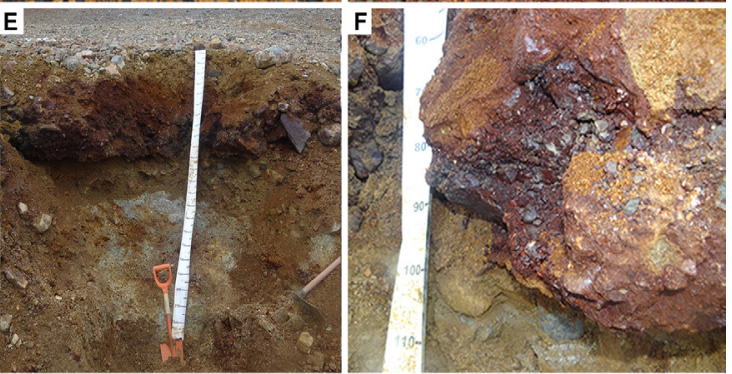

d) "Sulfuric" Haploturbel in Keller,

e) "Sulfuric" Petraquepts in Barton,

f) Fe cemented concretionary horizon in Barton; JRA: g) Pyritized sandstones (below), h) Sulfate affected landscape in Vega, i) Sulfate affected landscape in Seymour, j) "Sulfuric" Haploturbel
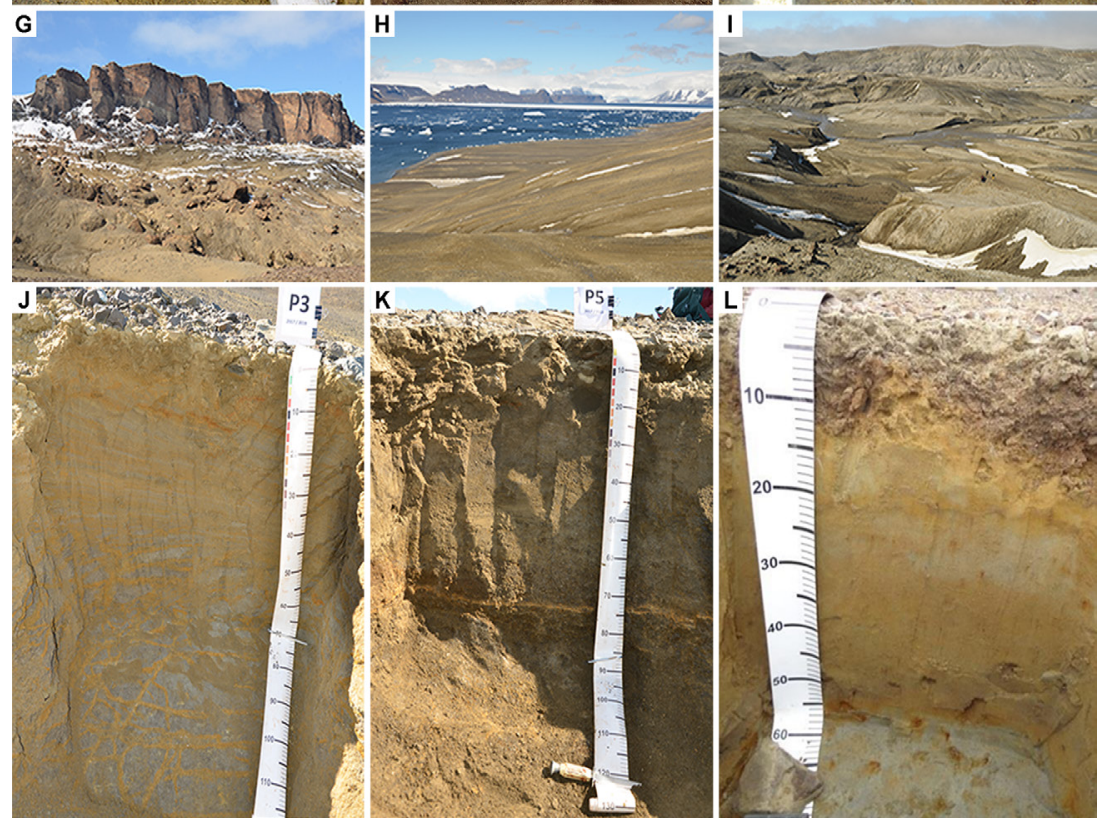
in Vega, k) "Sulfuric" Haploturbel in Vega, I) Typic ("Sulfuric") Psammorthel in Seymour.

at a higher latitude in relation to MA (between $63^{\circ} 50^{\prime}$ and $65^{\circ} \mathrm{S}$ ) (Fig. 1). The largest ice-free areas are in James Ross Island, Vega Island, and Seymour Island. The local deglaciation started 7.4 to 4.7 Ky BP (Hjort et al. 1997).

The semiarid climate in JRA is considered transitional between the warmer MA and the Continental Antarctica cold desert (Balks et al. 2013). The mean annual temperature ranges between $-5.5^{\circ} \mathrm{C}$ on Seymour Island to $-7^{\circ} \mathrm{C}$ on James Ross Island, and the summer averages are always negative (Hrbáček et al. 2017). The mean annual precipitation ranges from 300 to
500 mm (van Lipzig et al. 2004). The drier colder climate in relation to MA happens because the Antarctic Peninsula acts as a barrier to oceanic and atmospheric thermal exchange generated by the westerly Antarctic Circumpolar Current (Schaefer et al. 2015).

Due to the semiarid climate and cold temperatures, the vegetation cover is scarce, with rare small moss communities. JRA soils reflect a transitional character, with cryoturbation interplaying with typical cold desert processes, such as salinization and desert pavement formation (Daher et al. 2019). The main soils 
are Gelisols, due to the continuous permafrost, which can be ice-cemented or dry-frozen, depending on the regime of soil aridity of each island (Daher et al. 2019). The ice-free areas have a mountainous, hilly, strongly eroded topography (Davies et al. 2013). The presence of periglacial and paraglacial features superimposed upon remnant glacial surfaces reflects the post-glacial evolution of the JRA landscapes (Jennings et al. 2021).

The geological setting of the JRA belongs to the back-arc James Ross basin. Weakly lithified sandstones and mudstones of great fossiliferous richness compose the Upper Cretaceous to Paleogene marine sediments, which were overlaid by Neogene basaltic rocks (Pirrie et al. 1991). The Marambio Group and Seymour Island Group sedimentary rocks present pyrite as a common accessory mineral, formed by the biological reduction in shallow to deltaic sedimentation marine settings (Pirrie 1994). Such pyritized strata is further oxidized, resulting in acid sulfate soils formation (Fig. 2).

\section{Soil samples}

We analyzed an array of 40 acid sulfate soils of MA and JRA, compiled from various pedologic studies from the Brazilian Terrantar Group, involving similar morphological, chemical, physical and mineralogical analysis. In MA, the sulfate soils (15) are mainly concentrated in King George Island, particularly in Keller Peninsula (central Admiralty Bay), with five pedons, and in Barton Peninsula, with nine pedons (Francelino et al. 2011, Lopes et al. 2019). One single sulfate soil was described in Livingston Island (Byers Peninsula). In JRA, twenty-tree acid sulfate soils were reported in two islands: Vega Island (Cape Lamb), with ten pedons (Siqueira et al. 2021), and Seymour Island (Fig. 1), totalizing 13 pedons (Delpupo et al. 2014, Gjorup et al. 2020). All soils were classified according to Soil Taxonomy (Soil Survey Staff 2014).

\section{Soil properties}

The physical, chemical and mineralogical soil properties analyzed in this work were obtained according to Embrapa standards (2017). Soil fractions were determined by the pipette method after chemical and mechanical dispersion. This method involves sieving and weighing of coarse and fine sand, and sedimentation of silt followed by siphoning of the $<2 \mu \mathrm{m}$ fraction (Ruiz 2005).

Among the chemical properties, we used the soil $\mathrm{pH}$, determined in $\mathrm{H}_{2} \mathrm{O}$ mol L-1 in a 1:2.5 soil-liquid ratio; available $\mathrm{P}, \mathrm{K}, \mathrm{Na}$, extracted using Mehlich-1 $\left(\mathrm{HCl} 0.05 \mathrm{~mol} \mathrm{~L}^{-1}\right.$ and $\mathrm{H}_{2} \mathrm{SO}_{4}$ $0.025 \mathrm{~mol} \mathrm{~L}^{-1}$ ); exchangeable $\mathrm{Ca}^{2+}, \mathrm{Mg}^{2+}$ and $\mathrm{Al}^{3+}$, extracted with $\mathrm{KCl} 1 \mathrm{~mol} \mathrm{~L}^{-1}$ solution; potential acidity $(\mathrm{H}+\mathrm{Al})$, extracted with $\mathrm{Ca}\left(\mathrm{CH}_{3} \mathrm{COO}_{2}\right) 0.5$ mol L ${ }^{-1}$ solution, buffered at $\mathrm{pH} 7$; remaining $\mathrm{P}$, obtained after shaking $5 \mathrm{~g}$ of soil with a $\mathrm{CaCl}_{2}$ $0.01 \mathrm{~mol} \mathrm{~L}^{-1}$ solution containing $60 \mathrm{mg} \mathrm{L}^{-1}$ of $\mathrm{P}$ for $1 \mathrm{~h}$; bases sum - $\mathrm{BS}\left(\mathrm{Ca}^{2+}+\mathrm{Mg}^{2+}+\mathrm{K}^{+}+\mathrm{Na}^{+}\right)$; effective cation exchange capacity - eCEC $\left(\mathrm{BS}+\mathrm{Al}^{3+}\right)$; potential cation exchange capacity $(B S+\mathrm{H}+\mathrm{Al})$; and total organic carbon (TOC), determined by wet combustion (Yoemans \& Bremner 1988). The clay-sized minerals presented here were previously identified with $\mathrm{X}$-ray diffraction (XRD) analysis, using oriented clay samples and additional chemical treatments for identification of 2:1 clay-minerals and/or Fe-oxides (Simas et al. 2006).

\section{Statistical analysis}

We performed descriptive statistics (mean, median, maximum, minimum, standard deviation) of the acid sulfate soils. After, we calculated the Pearson Correlation index to analyze the association among the variables and performed a Principal Component Analysis (PCA) to clarify the most important soil variables. Finally, we performed the nonparametric Kruskal Wallis test, aiming to know 
if the differences between MA and JRA soils were statistically significant. All analyses were applied using the statistical software R (R Core Team 2021).

\section{RESULTS}

\section{Descriptive statistics of soil properties}

Soils are sandy, and the coarse sand was the main soil fraction of the MA sulfate soils, with average contents varying between 39.75 to
$61.88 \%$. The maximum value was found in Barton Peninsula (89\%). On the other hand, the fine sand, with little contribution in MA, averaged of 44.12 to $50.38 \%$ in sulfate soils from JRA. The highest contents were found in Seymour Island (90\%) (Table I).

The greatest average contents of clay were found in Vega Island (20.23\%), with maximum of $37.66 \%$, whereas the Seymour Island values were considerably lower (average of $13.10 \%$ ). In MA, clay contents were higher in Keller (average

Table I. Descriptive statistics (mean - median - minimum - maximum - standard deviation) for chemical and physical soil properties.

\begin{tabular}{|c|c|c|c|c|c|c|c|c|c|c|c|c|c|c|c|c|c|c|}
\hline & Depth & $\mathbf{C S}^{1}$ & $\mathrm{FS}^{2}$ & Silt & Clay & pH & $\mathbf{P}$ & K & $\mathrm{Na}$ & $\mathrm{Ca}^{2+}$ & $\mathrm{Mg}^{2+}$ & $\mathrm{Al}^{3+}$ & $\mathrm{H}+\mathrm{Al}$ & $\mathrm{BS}^{3}$ & eCEC ${ }^{4}$ & $\mathrm{CEC}^{5}$ & TOC $^{6}$ & P-rem \\
\hline & $\mathrm{cm}$ & \multicolumn{4}{|c|}{-------------\%------------- } & & \multicolumn{3}{|c|}{-------mg kg-1------- } & \multicolumn{7}{|c|}{ 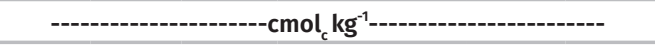 } & $\%$ & mg. $L^{-1}$ \\
\hline & & \multicolumn{17}{|c|}{ Maritime Antarctica } \\
\hline & & \multicolumn{17}{|c|}{ Barton Peninsula $\left(n^{*}=32\right)$} \\
\hline Mean & 89 & 42.78 & 14.91 & 25.06 & 17.25 & 4.66 & 82.68 & 45.44 & 67.81 & 4.74 & 1.92 & 3.68 & 10.06 & 7.12 & 10.79 & 17.18 & 1.25 & 16.88 \\
\hline Median & 51 & 41.00 & 11.00 & 25.00 & 15.50 & 4.51 & 18.90 & 25.50 & 50.75 & 3.00 & 0.46 & 3.10 & 9.20 & 3.83 & 7.72 & 13.84 & 0.26 & 15.50 \\
\hline Minimum & 25 & 10.00 & 4.00 & 3.00 & 4.00 & 2.92 & 2.90 & 0.00 & 14.40 & 0.22 & 0.06 & 0.00 & 2.80 & 0.39 & 2.72 & 6.02 & 0.10 & 3.30 \\
\hline Maximum & 220 & 89.00 & 42.00 & 50.00 & 38.00 & 6.58 & 649.50 & 255.00 & 173.60 & 20.82 & 9.93 & 9.60 & 31.70 & 30.72 & 32.82 & 36.82 & 11.08 & 41.60 \\
\hline \multirow[t]{2}{*}{ SD } & 74 & 17.53 & 9.53 & 11.26 & 8.06 & 1.06 & 153.70 & 55.53 & 46.55 & 5.22 & 3.25 & 2.77 & 6.66 & 8.48 & 7.73 & 8.46 & 2.28 & 9.81 \\
\hline & & \multicolumn{17}{|c|}{ Keller Peninsula $\left(n^{*}=15\right)$} \\
\hline Mean & 43 & 39.75 & 15.75 & 27.50 & 18.90 & 4.85 & 34.18 & 54.73 & 95.55 & 11.00 & 5.73 & 17.08 & 23.05 & 17.10 & 34.40 & 38.80 & 0.85 & 4.82 \\
\hline Median & 40 & 36.00 & 7.00 & 49.00 & 19.00 & 4.80 & 21.00 & 42.00 & 96.00 & 10.00 & 5.00 & 15.00 & 20.10 & 18.80 & 37.30 & 40.30 & 0.30 & 3.00 \\
\hline Minimum & 30 & 25.00 & 2.00 & 20.00 & 1.00 & 4.30 & 13.00 & 15.00 & 18.00 & 4.00 & 0.00 & 0.10 & 1.50 & 5.30 & 16.50 & 20.80 & 0.10 & 0.00 \\
\hline Maximum & 60 & 76.00 & 22.00 & 66.00 & 22.00 & 5.60 & 96.00 & 116.00 & 166.00 & 20.00 & 13.00 & 36.00 & 42.70 & 30.90 & 49.40 & 53.40 & 2.80 & 12.00 \\
\hline \multirow[t]{2}{*}{ SD } & 15 & 14.74 & 6.34 & 18.80 & 9.88 & 0.46 & 27.40 & 38.76 & 42.14 & 5.35 & 4.58 & 14.80 & 14.60 & 9.05 & 11.50 & 10.50 & 1.08 & 4.85 \\
\hline & & \multicolumn{17}{|c|}{ Byers Peninsula $\left(n^{*}=4\right)$} \\
\hline Mean & 115 & 61.88 & 5.48 & 18.83 & 13.78 & 4.19 & 2.38 & 37.00 & 154.40 & 15.82 & 0.79 & 13.04 & 18.70 & 17.38 & 30.42 & 36.08 & 0.09 & 9.25 \\
\hline Median & -- & 61.80 & 5.05 & 16.75 & 11.30 & 4.03 & 2.40 & 32.00 & 156.90 & 14.23 & 0.52 & 13.43 & 18.85 & 16.06 & 28.71 & 33.71 & 0.10 & 7.85 \\
\hline Minimum & -- & 49.70 & 2.70 & 10.70 & 3.60 & 3.69 & 0.90 & 22.00 & 136.10 & 5.20 & 0.28 & 10.80 & 16.50 & 6.52 & 20.83 & 27.12 & 0.00 & 3.00 \\
\hline Maximum & -- & 74.20 & 9.10 & 31.10 & 28.90 & 5.00 & 3.80 & 62.00 & 167.90 & 29.64 & 1.85 & 14.50 & 20.60 & 30.88 & 43.43 & 49.78 & 0.34 & 18.30 \\
\hline \multirow[t]{3}{*}{ SD } & -- & 10.00 & 2.66 & 8.68 & 10.76 & 0.57 & 1.39 & 18.51 & 13.31 & 11.67 & 0.71 & 1.73 & 1.68 & 11.25 & 10.07 & 10.48 & 0.17 & 7.21 \\
\hline & & \multicolumn{17}{|c|}{ James Ross Archipelago } \\
\hline & & \multicolumn{17}{|c|}{ Vega Island $\left(n^{*}=26\right)$} \\
\hline Mean & 89 & 5.10 & 44.12 & 30.72 & 20.23 & 4.96 & 24.72 & 99.59 & 808.00 & 17.20 & 4.99 & 4.20 & 6.74 & 25.96 & 30.17 & 32.69 & 0.26 & 19.55 \\
\hline Median & 100 & 2.87 & 50.94 & 23.28 & 20.53 & 4.21 & 14.20 & 89.00 & 419.00 & 13.70 & 4.95 & 3.25 & 5.80 & 21.10 & 24.80 & 26.60 & 0.29 & 19.70 \\
\hline Minimum & 29 & 0.42 & 3.34 & 15.16 & 1.27 & 2.75 & 2.30 & 14.00 & 150.00 & 6.94 & 0.98 & 0.00 & 0.00 & 11.80 & 16.70 & 17.00 & 0.00 & 5.00 \\
\hline Maximum & 130 & 23.81 & 63.43 & 72.12 & 37.66 & 8.13 & 160 & 330.00 & $3,438.0$ & 46.20 & 12.00 & 19.00 & 25.10 & 65.20 & 74.70 & 81.40 & 0.66 & 33.20 \\
\hline \multirow[t]{2}{*}{ SD } & 39 & 5.68 & 18.44 & 16.34 & 6.80 & 1.81 & 30.67 & 74.88 & 851.60 & 10.16 & 2.11 & 5.09 & 6.40 & 14.04 & 16.61 & 17.73 & 0.15 & 8.17 \\
\hline & & \multicolumn{17}{|c|}{ Seymour Island $\left(n^{*}=51\right)$} \\
\hline Mean & 88 & 9.13 & 50.38 & 26.86 & 13.10 & 5.32 & 47.44 & 111.50 & $1,528.0$ & 8.29 & 7.03 & 7.03 & 2.76 & 22.25 & 25.01 & 29.28 & 0.67 & 27.45 \\
\hline Median & 70 & 1.00 & 52.50 & 27.50 & 11.50 & 4.40 & 27.25 & 29.50 & $1,069.0$ & 6.84 & 7.13 & 4.50 & 0.59 & 20.32 & 24.11 & 28.96 & 0.65 & 28.80 \\
\hline Minimum & 54 & 0.00 & 10.00 & 2.00 & 1.00 & 2.99 & 7.70 & 3.00 & 40.90 & 1.76 & 0.37 & 0.20 & 0.00 & 3.66 & 4.60 & 6.92 & 0.08 & 3.50 \\
\hline Maximum & 220 & 56.00 & 90.00 & 61.00 & 58.00 & 8.90 & 393.60 & 936.00 & $4,765.0$ & 25.14 & 15.40 & 35.30 & 21.56 & 50.76 & 50.96 & 59.97 & 1.91 & 47.20 \\
\hline SD & 47 & 15.78 & 20.36 & 13.85 & 10.62 & 2.09 & 58.80 & 231.30 & 1335.0 & 5.69 & 4.56 & 8.18 & 4.39 & 11.46 & 12.52 & 14.64 & 0.41 & 10.63 \\
\hline
\end{tabular}

${ }^{1}$ coarse sand, ${ }^{2}$ fine sand, ${ }^{3}$ bases sum, ${ }^{4}$ effective cation exchange capacity, ${ }^{5}$ potential cation exchange capacity, ${ }^{6}$ total organic carbon. ${ }^{*}$ number of samples. 
of $18.90 \%$ ), closely followed by the sulfate soils from Barton. Barton acid sulfate soils showed the greatest depth variations in MA, with the greatest maximum and minimum values (220 and $25 \mathrm{~cm}$ ). In JRA, the maximum depth was found in Seymour $(220 \mathrm{~cm})$ and the minimum in Vega Island $(29 \mathrm{~cm})$ (Table I).

The MA acid sulfate soils showed more acidic pH levels (mean < 4.8) than JRA (mean $<5.3$ and maximum 8.9) (Table I), reflecting the different climates and buffering capacity. The maximum MA values do not reach neutrality $(\mathrm{pH})$, with the highest value in Barton (6.58). On the contrary, although the clear existence of sulfuric horizons with $\mathrm{pH}<3.5$ in JRA, strongly alkaline horizons (8.5 - 9.0) (Seymour Island) and moderately alkaline (7.9 - 8.4) (Vega Island) are also identified, resulting in greater standard deviations in the $\mathrm{pH}$ units (Table I).

The highest values of basic cations were found in JRA, with mean values of BS $>20 \mathrm{cmol}_{c}$ $\mathrm{kg}^{-1}$ and maximum values reaching $65 \mathrm{cmol}_{\mathrm{c}}$ $\mathrm{kg}^{-1}$ in Vega Island. Among the bases, the $\mathrm{Na}$ contents presented the highest variation. In JRA, the mean values were $808 \mathrm{mg} \mathrm{kg}^{-1}$ in Vega Island and $722 \mathrm{mg} \mathrm{kg}^{-1}$ in Seymour Island with maximum value reaching $4,764 \mathrm{mg} \mathrm{kg}^{-1}$. In MA, the maximum values not reach $200 \mathrm{mg} \mathrm{kg}^{-1}$. A contrasting pattern was identified for $\mathrm{Al}^{3+}$ and $\mathrm{H}+\mathrm{Al}$. The highest values were found in Keller Peninsula (average values of 17 and $23 \mathrm{cmol}_{\mathrm{c}} \mathrm{kg}^{-}$ ${ }^{1}$, respectively). In turn, the lowest $\mathrm{Al}^{3+}$ and $\mathrm{H}+\mathrm{Al}$ values were found in Seymour and Vega Island, respectively. The highest values of eCEC and CEC were found in Keller, Byers, and Vega Island (30$36 \mathrm{cmol}_{\mathrm{c}} \mathrm{kg}^{-1}$ ) (Table I).

The MA sulfate soils showed the greatest TOC contents and available $P$, with the only exception by a pedon found in Byers, where local environmental conditions did not allow organic matter accumulation. The highest values of TOC and P were found in Barton (mean of 1.25
$\%$ and $82.68 \mathrm{mg} \mathrm{kg}^{-1}$, respectively). The P-rem (an indicator of $\mathrm{P}$ adsorption capacity) was higher in JRA, highlighting the Seymour Island sulfate soils, with a mean of $27.45 \mathrm{mg} \mathrm{L}^{-1}$ (Table I).

\section{Statistical analyses}

Plotting the most important soil properties in a PCA 2D-plot, we observed that the spatial distribution of the two soil groups used was consistent with the variable orientation imposed on the PCA plot, marking a clear distinction between the acid sulfate soils of MA and JRA (Fig. 3). The two main components ( $P C^{\prime}$ 's) explained together $50.6 \%$ of the data variance, with the first component explaining $32.5 \%$ and the second one explaining $18.1 \%$. The potential acidity $(\mathrm{H}+\mathrm{Al})$ was the soil property with the highest loading for the two dimensions, contributing with $13.04 \%$ of the total, followed by the $\mathrm{Al}^{3+}$ (12.86\%), P-rem $(12.22 \%)$, coarse sand $(10.77 \%)$, and fine sand (10.32\%). The P, TOC, and clay were the variables with the lowest strength, although their higher importance for the second dimension (Fig. 3).

According to the PCA, the MA acid sulfate soils, plotted mostly in the negative PC1 quadrants, mainly distinguished by the projection of the variables coarse sand, $\mathrm{H}+\mathrm{Al}, \mathrm{Al}^{3+}, \mathrm{P}, \mathrm{TOC}$ and clay. On the other hand, the group of the JRA sulfate soils was mostly plotted in the opposite area with respect to the MA group (positive PC2 quadrants), being mainly distinguished by the higher contents of fine sand, P-rem, BS, Na, and $\mathrm{pH}$. The strongest positive Pearson correlations were found for the pairs $\mathrm{H}+\mathrm{Al}$ and $\mathrm{Al}^{3+}$ ( $\mathrm{r}$ : 0.77), projected in the negative $\mathrm{PC1}$, positive $\mathrm{PC2}$ quadrant; and $\mathrm{BS}$ and $\mathrm{Na}$ ( $r$ : 0.69), projected in the positive PC1, positive PC2 quadrant. Other lesser obvious positive correlations involved $\mathrm{P}$ with TOC (0.53) and $\mathrm{H}+\mathrm{Al}(0.24)$; TOC with $\mathrm{H}+\mathrm{Al}$ (0.20); fine sand with P-rem (0.53), $\mathrm{Na}(0.26)$ and $\mathrm{pH}$ (0.21); P-rem with pH (0.44) and $\mathrm{Na}$ (0.33); and clay with $\mathrm{Al}^{3+}$ (0.22) (Table II). 


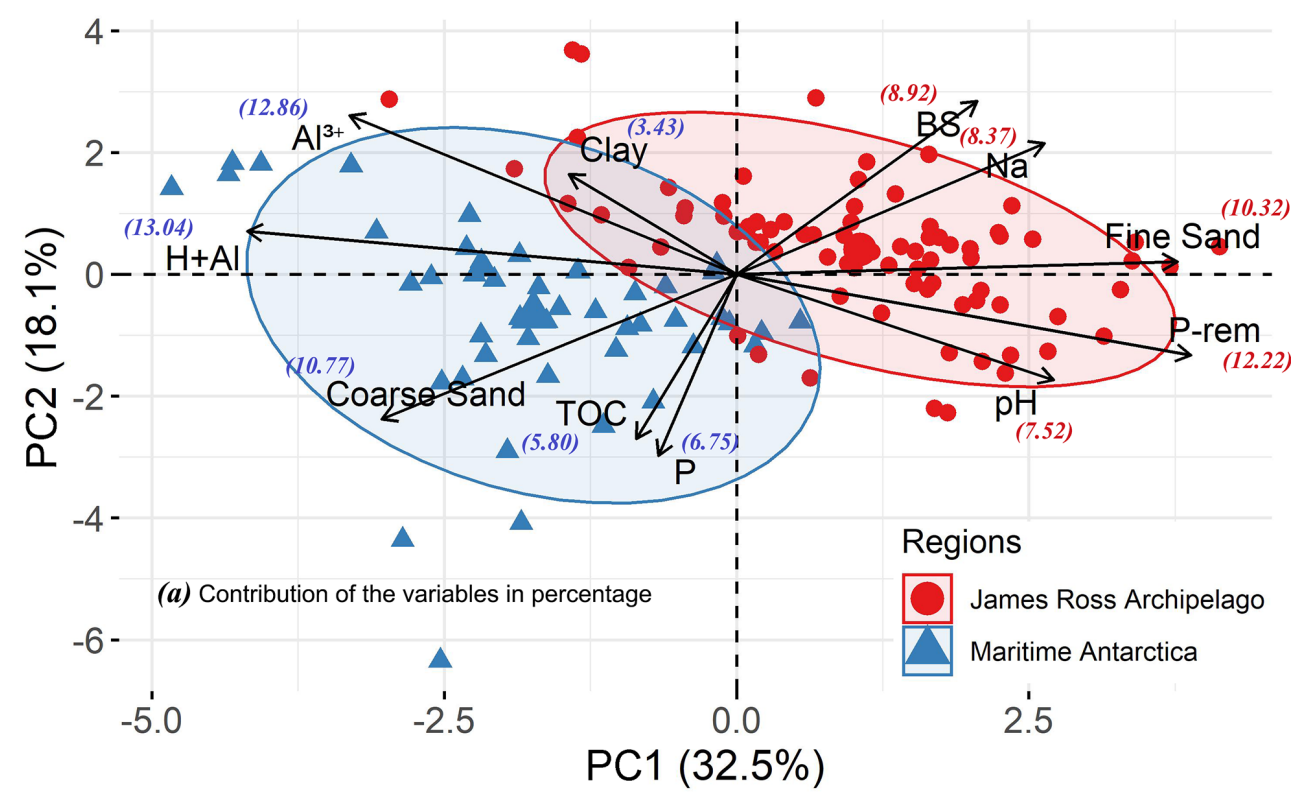

Figure 3. Principal Component Analysis of the Antarctic acid sulfate soils.

The main negative correlations were found for variables of opposite orientations with projection angle $>90^{\circ}$, highlighting the pairs fine sand and coarse sand (-0.70), fine sand and $\mathrm{H}+\mathrm{Al}(-0.53)$; P-rem and $\mathrm{H}+\mathrm{Al}(-0.60)$; P-rem and $\mathrm{Al}^{3+}(-0.56) ; \mathrm{pH}$ and $\mathrm{H}+\mathrm{Al}(-0.50)$; coarse sand and $\mathrm{Na}(-0.43)$; coarse sand and SB (-0.41); and coarse sand and P-rem (-0.31). Differently what happened to the negative correlation between clay and coarse sand (-0.12), the negative correlation between clay and fine sand (-0.38) was statistically significant, evidencing the opposition of these two physical variables in the context analyzed. Overall, the pairwise correlation clearly showed the contrast among the main explaining properties of MA and JRA acid sulfate soils (Table II).

Applying the Kruskal Wallis test, the soil properties whose average values presented statistically significant differences between the MA and JRA acid sulfate soils were the coarse sand, fine sand, $\mathrm{H}+\mathrm{Al}_{1} \mathrm{Al}^{3+}, \mathrm{BS}, \mathrm{Na}$ and P-rem. Only clay, TOC and P presented non-significance (Fig. 4), not coincidentally, the variables with lesser contribution to the data variation according to the PCA (Fig. 3).

\section{DISCUSSION}

\section{Acid sulfate soils in semiarid landscapes of James Ross Archipelago}

The Vega Island sulfate soils were classified as "Sulfuric" Haploturbel (Fig. 2), due to the presence of permafrost and cryoturbation, besides the identification of sulfuric horizons ( $\mathrm{pH}$ < 3.5) (Siqueira et al. 2021). The subgroup "Sulfuric" is an adaptation in the Soil Taxonomy System (Soil Survey Staff 2014) for keying out appropriately the sulfate-affected Haploturbels, proposed for the first time by Simas et al. (2008). In Seymour Island the acid sulfate soils were mainly keyed as Haplorthels (Fig. 2), Anhyorthels, and Psammorthels (Delpupo et al. 2014, Gjorup et al. 2020), where cryoturbated horizons are rare, and dry-frozen permafrost also occurs (Table III).

Overall, these soils presented greyish sandy horizons (hue around 2.5Y) with the presence of yellow orangish mottling with hue of 10YR and high chroma developed from pyritized lenses (Table IV). Yellow to orange sulfuric horizons were also identified. Morphological features are related to the parent sandstones, such as the 
Table II. Pearson correlation between sulfate soil properties.

\begin{tabular}{|c|c|c|c|c|c|c|c|c|c|c|c|}
\hline & $\mathbf{C S}$ & $\mathbf{F S}$ & $\mathbf{C l a y}$ & $\mathbf{p H}$ & $\mathbf{P}$ & $\mathbf{N a}$ & $\mathbf{A \mathbf { l } ^ { + * }}$ & $\mathbf{H + A l}$ & $\mathbf{S B}$ & $\mathbf{T O C}$ & $\mathbf{P r e m}$ \\
\hline $\mathbf{C S}$ & 1.0 & $-0.70^{\star}$ & -0.12 & -0.08 & 0.17 & $-0.43^{\star}$ & 0.10 & $0.33^{\star}$ & $-0.41^{\star}$ & 0.17 & $-0.31^{\star}$ \\
\hline $\mathbf{F S}$ & - & 1.00 & $-0.38^{\star}$ & $0.21^{\star}$ & -0.10 & $0.26^{\star}$ & $-0.35^{\star}$ & $-0.53^{\star}$ & 0.08 & -0.15 & $0.53^{\star}$ \\
\hline Clay & -- & -- & 1.00 & -0.12 & -0.07 & -0.05 & $0.22^{\star}$ & 0.14 & -0.01 & -0.04 & $-0.24^{\star}$ \\
\hline $\mathbf{p H}$ & - & - & -- & 1.00 & 0.07 & 0.14 & $-0.44^{\star}$ & $-0.50^{\star}$ & 0.12 & 0.03 & $0.44^{\star}$ \\
\hline $\mathbf{P}$ & - & - & -- & - & 1.00 & -0.04 & -0.11 & $0.24^{\star}$ & $-0.17^{\star}$ & $0.53^{\star}$ & 0.11 \\
\hline $\mathbf{N a}$ & - & - & -- & - & - & 1.00 & -0.07 & $-0.25^{\star}$ & $0.69^{\star}$ & -0.03 & $0.33^{\star}$ \\
\hline $\mathbf{A l} \mathbf{3}^{+}$ & - & - & -- & - & - & - & 1.00 & $0.77^{\star}$ & 0.00 & -0.11 & $-0.56^{\star}$ \\
\hline $\mathbf{H + A l}$ & - & - & -- & - & - & - & - & 1.00 & $-0.18^{\star}$ & $0.20^{\star}$ & $-0.60^{\star}$ \\
\hline $\mathbf{S B}$ & - & - & -- & - & - & - & - & - & 1.00 & -0.13 & 0.15 \\
\hline TOC & - & - & -- & - & - & - & - & - & - & 1.00 & -0.03 \\
\hline Prem & - & - & -- & - & - & - & - & - & - & - & 1.00 \\
\hline
\end{tabular}

*Significantly different at $5 \%$ from Student's $t$-test $(p \leq 0.05)$.

single-grain structure and the fine sandy texture (Table III, IV). The loamy texture was restricted for some soils developed from mudstones (Delpupo et al. 2014).

Tatur et al. (1993) showed that pyrite oxidation in JRA is directly mediated by acidophilic soil bacteria, despite the semiarid climate and the abiotic soil environment. Most JRA acid sulfate soils presented at least one horizon with $\mathrm{pH}<3.5$. In Vega Island, the acid sulfate soils presented a mean $\mathrm{pH}$ of 4.96 , whereas the basaltic soils presented an average of 7.72, with maximum values reaching up 9 (Siqueira et al. 2021). In Seymour Island, the sulfate soils showed a mean pH of 5.32, and nonsulfated sedimentary soils had a mean of 7.98 (Delpupo et al. 2014). Many sulfate soils showed extremely acidic sulfuric horizons concentrated in subsurface layers, while the surface horizons presented neutrally to alkaline conditions, with $\mathrm{pH}$ reaching values above 8 (Vega Island pedon, Table IV). Hence, the JRA acid sulfate soils showed hypereutric surface horizons and toxic contents of aluminum increasing with soil depth.
The contents of $\mathrm{Al}^{3+}$ reached up to about 20 $\mathrm{cmol}_{c} \mathrm{~kg}^{-1}$ in the sulfate soils of both islands, due to the extreme aluminum release from the aluminosilicates weathering and low $\mathrm{pH}$, whereas the non-sulfated soils generally presented null contents of $\mathrm{Al}^{3+}$ due to the high pH (Gjorup et al. 2020). A similar pattern occurred with $\mathrm{H}+\mathrm{Al}$ (Table I). Whereas other soils presented $\mathrm{H}+\mathrm{Al}$ values < $1 \mathrm{cmol}_{\mathrm{c}} \mathrm{kg}^{-1}$, the values of the acid sulfate soils were significantly higher $\left(>6 \mathrm{cmol}_{c} \mathrm{~kg}^{-1}\right.$ ) due to the formation of $\mathrm{pH}$-dependent charges (Table IV). In Vega Island, the base content in basaltic soils is twice higher than in acid sulfate soils (Siqueira et al. 2021), which can be associated with the original contents of the parent materials and the base leaching of the sulfate soils. The base leaching is most evident on Seymour Island, where the hypereutrophic non-sulfated sedimentary soils with bases saturation > 95\% give place to dystrophic sulfate soils with bases saturation as low as 41\% (Delpupo et al. 2014).

The main secondary minerals linked to the sulfurization in the JRA acid sulfate soils were jarosite and poorly-crystalline Fe-hydroxides (Table III, IV). Kaolinite was also identified, 

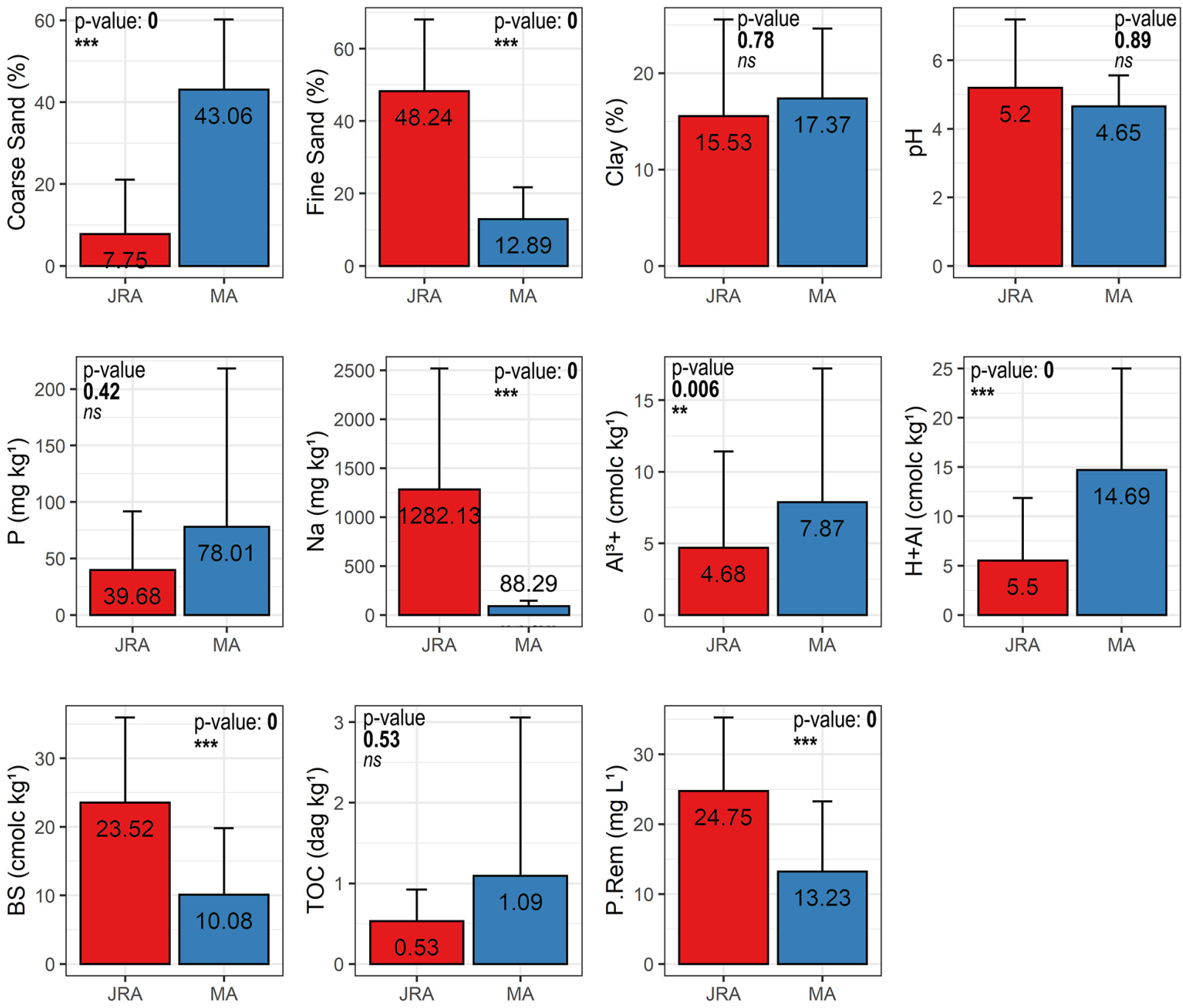

Figure 4. Average values and Kruskal Wallis test of selected variables for all horizons of the acid sulfate soils from MA and JRA. ns = non-significant; ${ }^{*} \mathrm{p} \leq 0.05 ;{ }^{* *} \mathrm{p} \leq 0.01 ;{ }^{* * *} \mathrm{p} \leq 0.001$.

but as a geogenic mineral inherited from the Cretaceous marine sediments (Pereira et al. 2013). Other common silicates of the clay fraction were the smectites and vermiculite, besides minerals such as quartz, plagioclase and K-feldspar (Table IV), evidencing the physical cryoclastic fractionation (frost weathering) of primary minerals due to the freeze-thaw cycles (Daher et al. 2019). Jarosite was the main sulfate mineral found in JRA soils. Both K-jarosite and natrojarosite were found by Delpupo et al. (2014) in Seymour Island. According to Tatur et al. (1993),
K-rich jarosite was usually found in deeper horizons of soils, while Na-rich forms were more commonly restricted to the surface horizons, especially in the sites close to the sea. Siqueira et al. (2021) found the K-rich jarosite as the main hydroxysulfate of Vega Island. Other minerals found in JRA sulfate soils were the Ca-sulfates gypsum and anhydrite (dehydrated gypsum), the latter identified only in the extreme semiarid pedoenvironments of Seymour Island (Table IV). Gypsum was found mainly in acid sulfate soils 
Table III. General characterization (climate, landscape, parent material, vegetation, soil classes) of the acid sulfate soils from Antarctica.

\begin{tabular}{|c|c|c|}
\hline & Maritime Antarctica & James Ross Archipelago \\
\hline Climate & $\begin{array}{c}\text { Sub-Antarctic cold, moist, maritime } \\
\text { climate }\end{array}$ & Subpolar, windy, semiarid climate \\
\hline Landscape & $\begin{array}{c}\text { Moraines, felsenmeers, outwash plains } \\
\text { and plateaus }\end{array}$ & Plains, terraces, hills and high steep slopes \\
\hline Parent material & $\begin{array}{l}\text { Sulfide-bearing basalt-andesitic rocks } \\
\text { and related till }\end{array}$ & $\begin{array}{l}\text { Fine, silty sandstones and bituminous silty } \\
\text { mudstones }\end{array}$ \\
\hline Vegetation & $\begin{array}{l}\text { Mosses, lichens and rare } \\
\text { Deschampsia sp. }\end{array}$ & Devoid of vegetation cover \\
\hline $\begin{array}{l}\text { Soil classes (Soil } \\
\text { Taxonomy) }\end{array}$ & $\begin{array}{l}\text { Gelisols ranging from Haploturbels } \\
\text { to Psammoturbels, and Inceptsols } \\
\text { (Petraquepts and Sulfaquepts) }\end{array}$ & $\begin{array}{c}\text { Gelisols including Haploturbels, Psammorthels, } \\
\text { Haplorthels and Anhyorthels }\end{array}$ \\
\hline Colors & $\begin{array}{l}\text { Pale yellowish colors to pinkish colors } \\
\text { in Fe-cemented concretionary horizons }\end{array}$ & $\begin{array}{l}\text { Sandy greyish soils with yellowish mottling. } \\
\text { Yellow orangish horizons }\end{array}$ \\
\hline Structure & $\begin{array}{l}\text { Single grain. Moderate, medium } \\
\text { granular and subangular blocks }\end{array}$ & $\begin{array}{c}\text { Generally loose, single grained. Massive in ice- } \\
\text { cemented permafrost }\end{array}$ \\
\hline Texture & $\begin{array}{l}\text { Sandy loam texture with more coarse } \\
\text { sand due to the parent material. Great } \\
\text { clay loads in sulfuric horizons }\end{array}$ & $\begin{array}{c}\text { Fine sandy texture with more clay in sulfuric } \\
\text { horizons. Loamy texture in soils from } \\
\text { mudstones }\end{array}$ \\
\hline pH & $\begin{array}{c}\text { Strongly to moderately acid in all } \\
\text { horizons }\end{array}$ & $\begin{array}{l}\text { Strongly acid in subsurface and alkaline to } \\
\text { strongly alkaline in surface horizons }\end{array}$ \\
\hline Clay mineralogy & $\begin{array}{l}\text { Vermiculite, montmorillonite, kaolinite, } \\
\text { illite-smectite, Al-hydroxy-interlayer } \\
\text { smectite, jarosite, goethite, ferrihydrite }\end{array}$ & $\begin{array}{c}\text { Quartz, K-feldspar, plagioclase, smectite, } \\
\text { vermiculite, kaolinite, illite, jarosite, } \\
\text { natrojarosite, gypsum, anhydrite, alunite, } \\
\text { ferrihydrite }\end{array}$ \\
\hline Permafrost & Ice-cemented. Absent in the Inceptisols & Ice-cemented and dry-frozen \\
\hline
\end{tabular}

rich in calcium sources, such as fossil biogenic carbonates.

Ferrihydrite was the main Fe-hydroxide, evidenced by the high contents of poorly crystalline $\mathrm{Fe}^{3+}$ (extracted by ammonium oxalate, McKeague \& Day 1966) of the JRA sulfate soils (Gjorup et al. 2020), which causes abundant positive soil charges, responsible for the very high adsorption capacity of the acid sulfate soils and very low available phosphorus contents, as low as $2.30 \mathrm{mg} \mathrm{kg}^{-1}$ (Table I). Ephemeral watersoluble sulfate salts were also found as products of the sulfurization in JRA (Tatur et al. 1993). In Seymour Island, the electrical conductivity of the acid sulfate soils reached up to $47 \mathrm{dS} \mathrm{m}^{-1}$ (Delpupo et al. 2014). In Vega Island, the sulfate soils presented the highest salt contents. In both islands, the Ca-Na sulfates seem to be the main salts present in the acid drainage. In the most acid soil of Vega Island ( $\mathrm{pH}=2.72)$, Siqueira et al. (2021) found a maximum of 1,200 $\mathrm{mg} \mathrm{kg}^{-1}$ of $\mathrm{SO}_{4}^{2-}$, whereas, in the groundwater, Moreno et al. (2012) found $\mathrm{SO}_{4}{ }_{4}^{2-}$ values of $2,570 \mathrm{mg} \mathrm{L}^{-1}$. The streams of Vega Island also showed extreme 
Table IV. Key morphological, physical and chemical indicators and clay mineralogy of representative acid sulfate soils.

\begin{tabular}{|c|c|c|c|c|c|c|c|c|c|}
\hline Horizons & Depth & Clay & pH & $\mathrm{H}+\mathrm{Al}$ & $\mathrm{Na}$ & P-rem & Structure & Munsell color (dry) & $\begin{array}{l}\text { XRD clay } \\
\text { mineralogy }\end{array}$ \\
\hline & $\mathrm{cm}$ & $\%$ & & $\mathrm{cmol}_{\mathrm{c}} \mathrm{kg}^{-1}$ & $\mathrm{mg} \mathrm{kg-1}$ & $m g L^{-1}$ & & & \\
\hline \multicolumn{10}{|c|}{ Vega Island - "Sulfuric" Haploturbel (Siqueira et al. 2021) } \\
\hline A & $0-8$ & 17.1 & 8.13 & 3.8 & 712 & 30.1 & sg & $2.5 Y 4 / 4$ & \multirow{4}{*}{$\begin{array}{l}\text { sme, kao, ill, } \\
\text { qtz, fel, jar, feh }\end{array}$} \\
\hline$A B$ & $8--41$ & 22.7 & 8 & 0.3 & 312 & 33.2 & sg & $2.5 Y 5 / 4$ & \\
\hline Bjjj1 & $41-69$ & 14.56 & 3.41 & 6.8 & 150 & 24.2 & sg & $2.5 Y$ 6/2-10YR 5/8 & \\
\hline Bjf2 & $69-110+$ & 22.19 & 3.45 & 5.8 & 200 & 31.6 & $\mathrm{ma}$ & $2.5 Y$ 6/2-10YR $7 / 4^{1}$ & \\
\hline \multicolumn{10}{|c|}{ Seymour Island - "Sulfuric" Anhyorthel (Delpupo et al. 2014) } \\
\hline $\mathrm{Aj}$ & $0-5$ & 21 & 5 & 3.2 & 3035.6 & 35.7 & sg & $2.5 Y 5 / 2$ & \multirow{5}{*}{$\begin{array}{c}\text { sme, plg, qtz, } \\
\text { nat, jar, gyp, } \\
\text { anh, all, feh }\end{array}$} \\
\hline$A C$ & $5--35$ & 2 & 7.1 & 0.2 & 2014.2 & 40 & sg & $5 Y 4 / 3$ & \\
\hline Cj1 & $35-40$ & 31 & 3.2 & 15 & 2039.1 & 23.9 & sg & $5 Y 5 / 2$ & \\
\hline Cjf2 & $40-55$ & 58 & 3.1 & 27.2 & 2811.4 & 22.8 & sg & $5 Y 5 / 2$ & \\
\hline Cjf3 & $55-88$ & 4 & 3.5 & 14.2 & 2412.8 & 22.6 & sg & $5 Y 5 / 2$ & \\
\hline \multicolumn{10}{|c|}{ Seymour Island - Typic Haplorthel (Gjorup et al. 2020) } \\
\hline A & $0-3$ & 28 & 3.25 & 15.5 & 549.5 & 16.11 & $\mathrm{sg}$ & 10YR $3 / 2$ & \multirow{3}{*}{$\begin{array}{l}\text { sme, ver, kao, } \\
\text { ill, qtz, jar, feh }\end{array}$} \\
\hline$B$ & $3--39$ & 25 & 3.1 & 17.2 & 731 & 11 & $\mathrm{sg}$ & 10YR 4/4 & \\
\hline Cf & $39-55$ & 22 & 4.27 & 6.6 & 4764.6 & 22.5 & $p$ & 10YR 4/1 & \\
\hline \multicolumn{10}{|c|}{ Keller Peninsula - "Sulfuric" Haploturbel (Francelino et al. 2011) } \\
\hline A & $0-10$ & 16 & 5.1 & 12 & 166 & 12 & sg & $2.5 Y 5 / 4$ & \multirow{4}{*}{$\begin{array}{l}\text { kao, chr, sme, } \\
\text { ill-sme, jar, feh }\end{array}$} \\
\hline B & $10--20$ & 1 & 5 & 20.1 & 125 & 3 & $w f g r$ & $2.5 Y 6 / 4$ & \\
\hline Cj1 & $20--30$ & 1 & 4.7 & 31 & 84 & 0 & $\mathrm{~m} \mathrm{~m} \mathrm{gr}$ & $2.5 Y 7 / 6$ & \\
\hline Cj2 & $30-40$ & 1 & 4.4 & 37 & 60 & 0 & $\mathrm{~m} \mathrm{~m} \mathrm{gr}$ & $2.5 Y 7 / 6$ & \\
\hline \multicolumn{10}{|c|}{ Barton Peninsula - “Sulfuric” Petraquepts (Lopes et al. 2019) } \\
\hline A & $0-20 / 29$ & 13 & 4.25 & 9.2 & 70.8 & 11.6 & sg & 10YR 7/4 & \multirow{5}{*}{$\begin{array}{c}\text { ver, sme, h-sme, } \\
\text { jar, feh, goe }\end{array}$} \\
\hline $\mathrm{Bj}$ & $20 / 29-36 / 40$ & 4 & 3.99 & 7.8 & 26.5 & 20.7 & sg & 5YR 5/6 & \\
\hline 2Bj1 & $36 / 40-90 / 94$ & 6 & 3.9 & 9.7 & 54.7 & 16.6 & md f sb & 10YR 8/3 & \\
\hline $2 \mathrm{Bj} 2$ & $90 / 94-130$ & 41 & 3.55 & 9.2 & 14.4 & 17 & $m d \mathrm{fsb}$ & $2 / 5 Y R ~ 8 / 4$ & \\
\hline 2Bjv3 & $130-140 / 165$ & 29 & 3.3 & 10.6 & 14.4 & 8 & $w f s b$ & 10YR 8/4 & \\
\hline \multicolumn{10}{|c|}{ Byers Peninsula - "Sulfuric” Haploturbel } \\
\hline Ajjj & $0-10$ & 12.5 & 5 & 18.8 & 167.85 & 3.9 & $w f s b$ & $5 Y R 5 / 8$ & \multirow{4}{*}{---} \\
\hline Bcij & $10--43$ & 28.9 & 4.14 & 20.6 & 157.92 & 3 & $w f s b$ & $10 R 3 / 3-10 R 3 / 6^{2}$ & \\
\hline Bij & $43-80$ & 10.1 & 3.92 & 16.5 & 136.08 & 11.8 & $w f s b$ & 7.5YR 5/4 & \\
\hline Ccrjf & $80-115+$ & 3.6 & 3.69 & 18.9 & 155.93 & 18.3 & $g r$ & $10 \mathrm{R} 4 / 8-10 \mathrm{R} 3 / 6^{2}$ & \\
\hline
\end{tabular}

${ }^{1}$ mottling color, ${ }^{2}$ nodules color. sg: single grain, ma: massive, $\mathrm{pl}$ : plate, $\mathrm{w} \mathrm{f}$ gr: weak fine granular, $\mathrm{m} \mathrm{m}$ gr: moderate medium granular, $\mathrm{md}$ f sb: moderate fine subangular blocks, $\mathrm{w} f \mathrm{sb}$ : weak fine subangular blocks, sme: smectite, ver: vermiculite, kao: kaolinite, ill: illite, ill-sme: illite-smectite, h-sme: hydroxy-interlayer smectite, chr: chlorite, qtz: quartz, fel: feldspar, plg: plagioclase, jar: jarosite, nat: natrojarosite, gyp: gypsum, anh: anhydrite, alu: alunite, feh: ferrihydrite, goe: goethite. 
acidity, with a pH of 3.7 and $2,680 \mathrm{mg} \mathrm{L}^{-1}$ of $\mathrm{SO}_{4}^{2}$ (Moreno et al. 2012).

Despite the typical sandy texture, the acid sulfate soils were characterized by the highest clay contents among JRA soils. In Vega Island, the sandy clay loam textural class predominates in the sulfate soils (with mean and maximum clay contents of 21 and 37\%), contrasting with other soils, whose mean clay contents were $14.77 \%$ for basaltic and $14.15 \%$ for non-sulfated sedimentary soils (Siqueira et al. 2021). The textural difference is important evidence about the active production of clay-sized minerals by the chemical weathering.

\section{Acid sulfate soils in Maritime Antarctica}

In Keller Peninsula, the acid sulfate soils were classified as "Sulfuric" Haploturbel (Fig. 2) (Simas et al. 2008). In Byers Peninsula, the sulfate soil found was also classified as Haploturbels, with permafrost at a $60 \mathrm{~cm}$ depth. In Barton Peninsula, Lopes et al. (2019) found a higher variability of acid sulfate soils, identifying Gelisols and Inceptsols in areas of discontinuous permafrost, including Petraquepts, Sulfaquepts, and Dystrocryepts (Table III, Fig. 2). The MA sulfate soils presented the typical yellow-orange colors (Table IV). In Keller Peninsula, Simas et al. (2006) found pale yellow colors directly related to jarosite. In the areas where the pyritized andesites are exposed, the yellowish colors of the sulfate soils contrast on a large scale with the lesser chromed surrounding basaltic soils (as in Yellow Point, Keller Peninsula) (Francelino et al. 2011). In Barton Peninsula, color gradient included yellowish brown (10YR), dark reddish brown (5YR), and pink (2.5YR 8/4). In Byers Peninsula, some horizons also presented very strong red colors (10 R) (Table IV).

The structure of the MA sulfate soils is mainly composed of weak to moderate, fine to medium granules, and subangular blocks (Table
III, IV). Simas et al. (2008) found that the low soil $\mathrm{pH}$ favored flocculation of fine particles and formation of stable, silt-sized, rounded, or ovoidal aggregates. The main soil texture found was sandy loam, with the domain of the coarse sand. The clay contents were slightly higher in the acid sulfate soils. In Byers and Barton, the clay contents of the sulfate soils were $\pm 3 \%$ higher than the common andesitic and basaltic soils, including extremely weathered ornithogenic soils, which consists in acidic soils originated under the influence of sea birds, with strong structure development, great clay contents, and formation of Fe-Al-phosphate minerals (Simas et al. 2007). In Keller, the presence of the siltsized stable aggregates favored by the low $\mathrm{pH}$ and cementation by Fe-hydroxides induced very low clay yields of some sulfuric horizons, with a minimum of $1 \%$ (Table IV).

The MA acid sulfate soils had significant chemical differences with the non-sulfated soils, which the main is the very low pH. Overall, the MA basaltic/andesitic soils had neutral to alkaline $\mathrm{pH}$. In Admiralty Bay (where Keller Peninsula is located), the basaltic/andesitic soils presented $\mathrm{pH}$ between 6 and 8 , with an average of 7.4 (Simas et al. 2008). In Byers Peninsula, the mean $\mathrm{pH}$ of soils from andesitic basalts was 7.2 (Moura et al. 2012). In turn, the MA acid sulfate soils presented $\mathrm{pH}$ mostly below 6, with few exceptions. In Keller Peninsula, the $\mathrm{pH}$ values of the sulfuric horizons were between 5 and 4 , whereas in Byers the lowest $\mathrm{pH}$ value was 3.69 (Table IV). The sulfate soils of Barton presented the most acidic samples, with some $\mathrm{pH}$ values < 3.5 and a minimum value of 2.92 (Table I).

The $\mathrm{Al}^{3+}$ and $\mathrm{H}+\mathrm{Al}$ contents increase abruptly with the acidity of the sulfate soils, contrasting strongly with the virtual absence of acidity in the basaltic soils (Francelino et al. 2011). In general, the $\mathrm{H}+\mathrm{Al}$ values of non-sulfated soils tend to be higher when there is a higher organic matter 
content (e.g., ornithogenic soils) (Michel et al. 2014, Rodrigues et al. 2019). Once the TOC values of the MA acid sulfate soils were considerably low (mean < $1.50{\text { dag } \mathrm{gg}^{-}}^{-1}$ ), the high $\mathrm{H}+\mathrm{Al}$ contents in MA sulfate soils (reaching $42.50 \mathrm{cmol}_{\mathrm{c}} \mathrm{kg}^{-1}$ in Keller) are supposed to be associated with the formation of $\mathrm{pH}$-dependent charges minerals, such as ferrihydrite and jarosite.

Simas et al. (2006) showed an abrupt decline of $266 \mathrm{mg} \mathrm{kg}^{-1}$ of $\mathrm{P}$ in the basaltic/andesitic soils to a mean value of 39.7 in the acid sulfate soils due to the strong phosphorus adsorption capacity of these soils. The differences are even higher when the sulfate soils are compared with the ornithogenic soils, which reach $\mathrm{P}$ mean values up to 1,356 $\mathrm{mg} \mathrm{kg}^{1}$ (Simas et al. 2008). The MA acid sulfate soils also presented a lower content of bases. Simas et al. (2008) showed that the basaltic/andesitic soils presented a mean $\mathrm{Ca}+\mathrm{Mg}$ content of $31.8 \mathrm{cmol}_{\mathrm{c}} \mathrm{kg}^{-1}$, whereas the acid sulfate soils presented approximately half of this content $\left(15.1 \mathrm{cmol}_{\mathrm{c}} \mathrm{kg}^{-1}\right)$ due to the weathering and leaching of bases.

Sulfurization was responsible for the production of acid drainage. In Keller, where the sulfide affected areas correspond to approximately $19 \%$ of the total area (Francelino et al. 2011), Souza et al. (2012) found eight sulfideaffected watersheds characterized by a sulfate concentration in surface water higher than 150 $\mathrm{mg} \mathrm{L}^{-1}$. In contrast, the water of non-affected watersheds showed a sulfate concentration around $70 \mathrm{mg} \mathrm{L}^{-1}$. The authors also found that the $\mathrm{SO}_{4}^{2-}$ presented a high correlation with $\mathrm{Ca}^{2+}$ and $\mathrm{Mg}^{2+}$, indicating the domain of calciummagnesium sulfate waters. In Barton, Lopes et al. (2021) verified that acidity production was responsible for the mobilization of metals such as $\mathrm{Al}, \mathrm{Cu}, \mathrm{Fe}, \mathrm{Mn}$, being this process fundamental for secondary minerals formation in the acid sulfate soils (e.g., precipitation of ferric iron in the form of Fe-hydroxides).
The main sulfate mineral was the jarosite, in balance with the acidic pH (Schaefer et al. 2008). Simas et al. (2006) showed that various amounts of $\mathrm{K}$ and $\mathrm{Na}$ in the different jarosite crystals indicate that jarosite is commonly intermediate to natrojarosite in Keller sulfate soils. Alhydroxy-interlayer smectites and kaolinite were also found as a product of intense chemical weathering and neominerals formation. Simas et al. (2006) stated that strong chemical weathering of the acid sulfate soils is also related to the absence of primary minerals in the clay fraction. The poorly crystalline ferrihydrite was the main Fe-hydroxide, responsible for the very low P-rem, with values even indicating total adsorption ( 0 $\mathrm{mg} \mathrm{L}^{-1}$ ) (Table IV).

In Barton Peninsula, Lopes et al. (2019) found concretionary soils (e. g. "Sulfuric" Petraquepts, Table IV) bearing ferruginous concretions (Fig. 2) with more than $70 \%$ of Fe (according to EDS$X$-ray microchemical analysis). The authors also showed that the ferruginous concretions are composed predominantly by goethite (a secondary crystalline Fe-hydroxide), which is unusual for Antarctic conditions, where shortrange-order Fe-hydroxides prevail. The presence of goethite was confirmed after chemical treatments to enhance the iron oxide XRD peaks, as described by Lopes et al. (2019).

Hematite, identified elsewhere in King George Island (Spinola et al. 2017), was not identified in Barton, leading to the assumption that the dark red colors are due to the ferrihydrite, not identifiable to XRD, besides the presence of $\mathrm{Mn}$ and other impurities. Both goethite and ferrihydrite can be products of jarosite hydrolysis, depending on soil redox potential and pH (Schaefer et al. 2008). Lopes et al. (2019) have suggested that the ferruginous concretions genesis is directly connected to the sulfurization process, with accumulation of Fe 
from the sulfides into new iron-rich mineral phases.

\section{Can acid sulfate soils have climate-induced pedological differences along a climatic gradient in Antarctica?}

The analyses of acid sulfate soils from the Antarctic Peninsula showed the MA acid sulfate soils presented a higher degree of pedogenetic development due to deeper chemical weathering and moisture availability. This development is originated from pyrite oxidation (sulfurization) and potentialized by climatic conditions (higher temperature and moisture). The MA mild, wetter climate favors the abiotic and biotic chemical reactions promoted by the sulfurization, the leaching of bases, and the non-accumulation of salts (Lopes et al. 2021). Considering only the parent materials, the James Ross Archipelago probably would have more developed acid sulfate soils due to the pre-weathered sedimentary rocks (Tatur et al. 1993). However, the analysis of the main chemical, morphological and mineralogical (Table IV) characteristics showed that the MA sulfate soils developed on volcanic rocks are more pedogenetically developed than their JRA counterparts.

Most acid sulfate soils were keyed out as Gelisols due to permafrost within $1 \mathrm{~m}$ from the surface (Soil Survey Staff 2014). In JRA, the acid sulfate soils without permafrost were classified as Entisols due to the absence of significant pedogenetic development (Siqueira et al. 2021). In MA, the permafrost-non-affected sulfate soils presented significant pedogenetic development to be classified as Inceptsols, with well-defined horizons and granular to blocky aggregates formation (Lopes et al. 2019). The soil aggregates formation is directly related to the MA wetting and drying cycles plus the cementation by the Fe-oxides in the acid sulfate soils (Simas et al. 2008). The unusual presence of ferruginous concretions and nodules, is also an evidence of the hydration and dehydration cycles to which the MA acid sulfate soils are under the influence.

One of the most differentiating characteristics between MA and JRA acid sulfate soils is their sand contents, which were not related to the weathering degree, but to the parent material constitution. The coarse sand is associated with the high resistance to fractionation by weathering of the MA basaltandesitic rocks, and the fine sand is closely related to the fine JRA Cretaceous sandstones, from which the acid sulfate soils developed. Although the mean clay values of MA soils were higher than that of the JRA soils, the differences were not significant (Fig. 3).

The great clay content suggests that weathering and formation of secondary minerals is active, which seems to be more pronounced in the sulfate soils on MA and Vega Island, but less important on Seymour Island. The cryoclasty, process of physical weathering responsible by the physical comminution of the soil particles by frost action, seems to be more important in JRA for clay production due to the predominance of quartz, a primary mineral with greater resistance to acidolysis (Gjorup et al. 2020). In Antarctica, many studies have showed that the cryoclasty is capable of producing soil particles as fine as clay, including in the Antarctic Peninsula region (Moreno et al. 2012, Pereira et al. 2013, Daher et al. 2019). Additionally, the JRA sedimentary lithology can also present many fine materials (mudstones) that are accumulated in soils as clays. In turn, the MA clayey soils of volcanic origin are associated exclusively with the catalysis of chemical weathering promoted by the sulfurization, unlike the JRA sites.

The MA sulfate soils showed the lowest base contents and the highest acidity due to weathering and leaching (Table I). Sulfate soils that undergo a long leaching period are 
depleted of bases, and their exchange complex is saturated with aluminum and $\mathrm{H}^{+}$(Dent 1986). The intense leaching of bases is in agreement with Lopes et al. (2021), who pointed out acid sulfate environments at Barton Peninsula have dystrophic soils, with high acidity and contents of fine particles.

In JRA, the sulfurization, although intense, is balanced by the effects of another important pedogenetic process: salinization, which is in direct relation with the semiarid climate of the archipelago. Salinization is a soluble-salt accumulation pedogenic process, common in the desertic environments of Antarctica (Bockheim \& McLeod 2006). The very high contents of $\mathrm{Na}$, mainly at the surface, are the primary evidence of the salinization in the JRA soils, besides salts accumulations as surface saline efflorescence. The salinization seems to be more expressive in Seymour Island, where the drier climate produced acid sulfate soils with $\mathrm{Na}$ values almost 30 times higher than any sulfate soil of MA (Gjorup et al. 2020).

The interaction between the salinization and the sulfurization produces acid sulfate soils with contrasting chemical characteristics among their horizons. Whereas extreme acidic sulfuric horizons are concentrated at depths of 40-50 $\mathrm{cm}$ from the surface, the superficial salt input, together with low leaching rates and depletion of the acid generation, contributes to the $\mathrm{pH}$ increase and recovery of the soil alkalinity (Siqueira et al. 2021). Furthermore, even the JRA acidic sulfuric horizons tend to present base contents higher than the MA soils, indicating lesser chemical transformations and leaching due to the lower water availability. The presence of easily weatherable minerals (K-feldspar and plagioclases) in the clay fraction also evidences the limited leaching and base output of the JRA sulfate soils (Table IV).
The acid sulfate soils are also characterized by possessing high $\mathrm{P}$ adsorption capacity, mainly due to the formation of iron oxyhydroxides of low crystallinity (Simas et al. 2006). Lower values of remaining $P$ in the MA acid sulfate soils indicate that the mineralogical transformations and positive charges are more intense in MA, with high $\mathrm{P}$ adsorption capacity in wetter climates. In particular, the presence of goethite $a$ is striking evidence of the degree of weathering of the MA acid sulfate soils, highlighting the Barton Peninsula soils, since the formation of this Fehydroxide requires a long time for increasing crystallinity, which is possible only with an appropriate long-term pedological evolution.

On the other hand, the higher levels of available phosphorus of MA acid sulfate soils in relation to the JRA soils were directly associated with the phosphatization, which consists of an essential Antarctic pedogenic process activated by the input of P-rich guano in soils from the widespread breeding of seabirds (mainly penguins) (Simas et al. 2007, Rodrigues et al. 2021). Higher TOC content of the MA sulfate soils, in turn, is related to the biological input of organic matter mainly from large bryophyte carpets (Michel et al. 2006), whereas the JRA soils are humus-poor due to the scarce vegetation and soil aridity (Daher et al. 2019). Both fauna and flora contribution are directly associated with the mild MA climatic conditions. However, the vegetative growth restrictions associated to the toxicity and nutrient deficiency of the acid sulfate soils allow TOC contents considerably lower than those found for other MA soils (Rodrigues et al. 2019), mainly the organic Histels (Soil Survey Staff 2014). 


\section{CONCLUSIONS}

1. The acid sulfate soils from Maritime Antarctica showed higher weathering degree and pedogenic development than the acid sulfate soils from James Ross Archipelago (Weddell Sea), although pyrite oxidation is the origin of both groups of soils.

2. The warmer and wetter Maritime Antarctica climate promotes pedogenesis, increasing the chemical reactions promoted by sulfurization process, leaching, and mineralogical transformations.

3. The sulfurization in James Ross Archipelago is balanced by the semiarid climate, resulting in a potential basicity able to exceed the acidity conditions, at least in the horizons with greater interactions with the dry atmosphere, or higher carbonate contribution and buffering.

4. In equilibrium with climatic conditions, sulfurization interact with other pedogenic processes. In Maritime Antarctica, acid sulfate soils are also subjected to phosphatization and organic matter accumulation, whereas in the James Ross Archipelago, these soils are influenced by salinization.

5. Even the Antarctic Peninsula acid sulfate soils, whose formation is strongly associated with the parent materials, have intermediary properties that can be interpreted according to a climate gradient. This finding corroborates the complexity of soil formation in this part of Antarctica, which cannot be seen as solely dependent on the parent material characteristics, but also on the climatic conditions.

\section{Acknowledgments}

This study was funded in part by the Coordenação de Aperfeiçoamento de Pessoal de Nivel Superior - Brasil (CAPES) - Finance Code 001. This work is a contribution of Institute of Science and Technology of the Cryosphere - TERRANTAR group (https://www.ufrgs.br/inctcriosfera/ terrantar.html).

\section{REFERENCES}

ALMEIDA ICC, SCHAEFER CEGR, FERNANDES RBA, PEREIRA TTC, NIEUWENDAM A \& PEREIRA AB. 2014. Active layer thermal regime at different vegetation covers at Lions Rump, King George Island, Maritime Antarctica. Geomorphology 225: 36-46.

BALKS MR, LÓPEZ-MARTÍNEZ J, GORYACHKIN SV, MERGELOV NS, SCHAEFER CEGR, SIMAS FNB, ALMOND PC, CLARIDGE GGC, MCLEOD M \& SCARROW J. 2013. Windows on Antarctic soillandscape relationships: Comparison across selected regions of Antarctica. Geol Soc Spec Publ 381: 397-410.

BIGHAM JM \& NORDSTROM DK. 2000. Iron and aluminum hydroxysulfates from acid sulfate waters. In: Alpers CN, Jambor JL \& Nordstrom DK (Eds), Sulfate Minerals: Crystallography, Geochemistry, and Environmental Significance, Washington DC: Mineralogical Society of America, p. 351-404.

BLUMEL WD \& EITEL B. 1989. Geoecological aspects of maritime-climatic and continental periglacial regions in Antarctica (South Shetlands, Antarctic Peninsula and Victoria Land). Geökodynamic 10: 201-214.

BOCKHEIM JG \& MCLEOD M. 2006. Soil formation in Wright Valley, Antarctica since the late Neogene. Geoderma 137: 109-116.

BOCKHEIM JG \& UGOLINI FC. 1990. A review of pedogenic zonation in well-drained soils of the southern circumpolar region. Quaternary Res 34: 47-66.

CAMPBELL IB \& CLARIDGE GGC. 1987. Antarctica: Soils, weathering processes and environment, Amsterdam: Elsevier, 368 p.

DAHER M, SCHAEFER CEGR, FERNANDES FILHO EI, FRANCELINO MR \& SENRA EO. 2019. Semi-arid soils from a topolithosequence at James Ross Island, Weddell Sea region, Antarctica: chemistry, mineralogy, genesis and classification. Geomorphology 327: 351-364.

DAVIES BJ, GLASSER NF, CARRIVICK JL, HAMBREY MJ, SMELLIE JL \& NÝVLT D. 2013. Landscape evolution and ice-sheet behaviour in a semi-arid polar environment: James Ross Island, NE Antarctic Peninsula. Geol Soc Spec Publ 381: 353-395.

DELPUPO CS, SCHAEFER CEGR, SIMAS FNB, SPINOLA DN \& DAHER M. 2014. Soil formation in Seymour Island, Weddell Sea, Antarctica. Geomorphology 255: 87-99.

DENT DL. 1986. Acid Sulfate Soils: a baseline for research and development, Publ39, Wageningen, The Netherlands: International Institute for Land Reclamation and Improvement ILRI, $204 \mathrm{p}$. 
DENT DL \& PONS LJ. 1995. A world perspective on acid sulphate soils. Geoderma 67: 263-276.

EMPRESA BRASILEIRA DE PESQUISA AGROPECUÁRIA - EMBRAPA. 2017. Manual de Métodos de Análise de Solo, 3a ed., Brasília: EMBRAPA, 574 p.

FERRARI FR, SCHAEFER CEGR, PEREIRA AB, SCHMITZ D \& FRANCELINO MR. 2020. Coupled soil-vegetation changes along a topographic gradient on King George Island, maritime Antarctica. Catena 198: 105038.

FRANCELINO MR, SCHAEFER CEGR, SIMAS FNB, FERNANDES-FILHO EI, SOUZA JJLL \& COSTA LM. 2011. Geomorphology and soils distribution under paraglacial conditions in an ice-free area of Admiralty Bay, King George Island, Antarctica. Catena 85: 194-204.

GJORUP DF, SCHAEFER CEGR, SIMAS FNB, FRANCELINO MR, MICHEL RFM \& BOCKHEIM JG. 2020. Sulfurization, acid-sulfate soils and active layer monitoring at the semiarid Seymour Island, Antarctica. Geoderma Reg 22: e00305.

HJORT C, INGÓLFSSON Ó, MÖLLER P \& LIRIO JM. 1997. Holocene glacial history and sea-level changes on James Ross Island, Antarctic Peninsula. J Quaternary Sci 12: 259-273.

HRBÁČEK F, NÝVLT D \& LÁSKA K. 2017. Active layer thermal dynamics at two lithologically different sites on James Ross Island, Eastern Antarctic Peninsula. Catena 149: 592-602.

INGÓLFSSON Ó \& HJORT C. 2002. Glacial history of the Antarctic Peninsula since the Last Glacial Maximum-a synthesis. Polar Res 21: 227-234.

JENNINGS SJA, DAVIES BJ, NÝVLT D, GLASSER NF, ENGEL Z, HRBÁČEK F, CARRIVICK JL, MLČOCH B \& HAMBREY MJ. 2021. Geomorphology of Ulu Peninsula, James Ross Island, Antarctica. J Maps 17: 125-139.

LOPES DV, SCHAEFER CEGR, SOUZA JJLL, OLIVEIRA FS, SIMAS FNB, DAHER M \& GJORUP DF. 2019. Concretionary horizons, unusual pedogenetic processes and features of sulfate affected soils from Antarctica. Geoderma 347: 13-24.

LOPES DV, SOUZA JJLL, SIMAS FNB, OLIVEIRA FS \& SCHAEFER CEGR. 2021. Hydrogeochemistry and chemical weathering in a periglacial environment of Maritime Antarctica. Catena 197: 104959.

LÓPEZ-MARTíNEZ J, SERRANO E, SCHMID T, MINK S \& LINÉS C. 2012. Periglacial processes and landforms in the South Shetland Islands (northern Antarctic Peninsula region). Geomorphology 155-156: 62-79.

MCKEAGUE JA \& DAY JH. 1966. Dithionite and oxalateextractable $\mathrm{Fe}$ and $\mathrm{Al}$ as aids in differentiating various classes of soils. Can J Soil Sci 46: 13-22.
MICHEL RFM, SCHAEFER CEGR, DIAS LE, SIMAS FNB, BENITES VM \& MENDONÇA ES. 2006. Ornithogenic Gelisols (Cryosols) from Maritime Antarctica: Pedogenesis, Vegetation, and Carbon Studies. Soil Sci Soc Am J 70: 1370-1376.

MICHEL RFM, SCHAEFER CEGR, POELKING EL, SIMAS FNB, FERNANDES FILHO EI \& BOCKHEIM JG. 2012. Active layer temperature in two Cryosols from King George Island, Maritime Antarctica. Geomorphology 155-156: 12-19.

MICHEL RFM, SCHAEFER CEGR, LÓPEZ-MARTÍNEZ J, SIMAS FNB, HAUS NW, SERRANO E \& BOCKHEIM JG. 2014. Soils and landforms from Fildes Peninsula and Ardley Island, Maritime Antarctica. Geomorphology 225: 76-86.

MORENO L, SILVA-BUSSO A, LÓPEZ-MARTÍNEZ J, DURÁN-VALSERO J), MARTÍNEZ-NAVARRETE C, CUCHÍ JÁ \& ERMOLIN E. 2012. Hydrogeochemical characteristics at Cape Lamb, Vega Island, Antarctic Peninsula. Antarct Sci 24: 591-607.

MOURA PA, FRANCELINO MR, SCHAEFER CEGR, SIMAS FNB \& MENDONÇA BAF. 2012. Distribution and characterization of soils and landform relationships in Byers Peninsula, Livingston Island, Maritime Antarctica. Geomorphology 155-156: 45-54.

NAVAS A, LÓPEZ-MARTÍNEZ J, CASAS J, MACHÍN J, DURÁN JJ, SERRANO E, CUCHI JÁ \& MINK S. 2008. Soil characteristics on varying lithological substrates in the South Shetland Islands, maritime Antarctica. Geoderma 144: 123-139.

ÖBORN I \& BERGGREN D. 1995. Characterization of jarositenatrojarosite in two northern Scandinavian soils. Geoderma 66: 213-225.

PEREIRA TTC, SCHAEFER CEGR, KER JC, ALMEIDA CC, ALMEIDA ICC \& PEREIRA AOB. 2013. Genesis, mineralogy and ecological significance of ornithogenic soils from a semi-desert polar landscape at Hope Bay, Antarctic Peninsula. Geoderma 209-210: 98-109.

PIRRIE D. 1994. Petrography and provenance of the Marambio Group, Vega Island, Antarctica. Antarct Sci 6: 517-527.

PIRRIE D, CRAME JA \& RIDING JB. 1991. Late Cretaceous stratigraphy and sedimentology of Cape Lamb, Vega Island, Antarctica. Cretaceous Res 12: 227-258.

POEKING EL, SCHAEFER CEGR, FERNANDES-FILHO EI, ANDRADE AM \& SPIELMANN AA. 2009. Soil - landform - plantcommunity relationships of a periglacial landscape on Potter Peninsula, Maritime Antarctica. Solid Earth 6: 583-594.

R CORE TEAM. 2021. R: A language and environment for statistical computing. R Foundation for Statistical Computing, Vienna, Austria. URL http://www.R-project. org/. 
RODRIGUES WF, OLIVEIRA FS, SCHAEFER CEGR, LEITE MGP, GAUZZI T, BOCKHEIM JG \& PUTZKE J. 2019. Soil-landscape interplays at Harmony Point, Nelson Island, Maritime Antarctica: Chemistry, mineralogy and classification. Geomorphology 336: 77-94.

RODRIGUES WF, OLIVEIRA FS, SCHAEFER CEGR, LEITE MGP \& PAVINATO PS. 2021. Phosphatization under birds' activity: Ornithogenesis at different scales on Antarctic Soilscapes. Geoderma 391: 114950.

RUIZ HA. 2005. Incremento da Exatidão da Análise Granulométrica do Solo por meio da Coleta da Suspensão (silte + argila). Rev Bras Cienc Solo 29: 297-300.

SCHAEFER CEGR, SIMAS FNB, GILKES RJ, MATHISON C, COSTA LM \& ALBUQUERQUE MA. 2008. Micromorphology and microchemistry of selected Cryosols from maritime Antarctica. Geoderma 144: 104-115.

SCHAEFER CEGR, DELPUPO CS, SIMAS FNB, GJORUP DF \& BOCKHEIM JG. 2015. Soils of the Weddell sea sector, Antarctica. In: Bockheim JG (Ed), The Soils of Antarctica, Cham: Springer International Publishing AG Switzerland, p. 227-273.

SIMAS FNB, SCHAEFER CEGR, MELO VF, GUERRA MBB, SAUNDERS $M$ \& GILKES RJ. 2006. Clay-sized minerals in permafrostaffected soils (Cryosols) from King George Island, Antarctica. Clay Clay Miner 54: 721-736.

SIMAS FNB, SCHAEFER CEGR, MELO VF, ALBUQUERQUE-FILHO MR, MICHEL RFM, PEREIRA VV, GOMES MRM \& COSTA LM. 2007. Ornithogenic cryosols from Maritime Antarctica: Phosphatization as a soil forming process. Geoderma 138: 191-203.

SIMAS FNB, SCHAEFER CEGR, ALBUQUERQUE-FILHO MR, FRANCELINO MR, FERNANDES-FILHO EI \& COSTA LM. 2008. Genesis, properties and classification of Cryosols from Admiralty Bay, maritime Antarctica. Geoderma 144: 116-122.

SIMAS FNB, SCHAEFER CEGR, MICHEL RFM, FRANCELINO MR \& BOCKHEIM JG. 2015. Soils of the South Orkney and South Shetland Islands, Antarctica. In: Bockheim JG (Ed), The Soils of Antarctica, Cham: Springer International Publishing AG Switzerland, p. 275-279.

SIQUEIRA RG, SCHAEFER CEGR, FERNANDES-FILHO EI, CORRÊA GR, FRANCELINO MR, SOUZA JJLL \& ROCHA PA. 2021. Weathering and pedogenesis of sediments and basaltic rocks on Vega Island, Antarctic Peninsula. Geoderma 382: 114707.

SOIL SURVEY STAFF 2014. Keys to Soil Taxonomy, $12^{\text {th }}$ ed, Washington DC: USDA Natural Resources Conservation Service, $372 \mathrm{p}$.
SOUZA JJLL, SCHAEFER CEGR, ABRAHÃO WAP, MELLO JWV, SIMAS FNB, SILVA J \& FRANCELINO MR. 2012. Hydrogeochemistry of sulfate-affected landscapes in Keller Peninsula, Maritime Antarctica. Geomorphology 155-156: 55-61.

SPINOLA DN, PORTES RC, SCHAEFER CEGR, SOLLEIROREBOLLEDO E, PI-PUIG T \& KÜHN P. 2017. Catena Eocene paleosols on King George Island, Maritime Antarctica: macromorphology, micromorphology and mineralogy. Catena 152: 69-81.

TATUR A, BARCZUK A, DEL VALLE R, SLETTEN R \& KICINSKA E. 1993. Surface mineralization on Seymour Island, Antarctica. Pol Polar Res 14: 153-168.

VAN LIPZIG NPM, KING JC, LACHLAN-COPE TA \& van den BROEKE MR. 2004. Precipitation, sublimation, and snow drift in the Antarctic Peninsula region from a regional atmospheric model. J Geophys Res 109: 1-16.

YOEMANS JC \& BREMNER JM. 1988. A rapid and precise method for routine determination of organic carbon in soil. Commun Soil Sci Plant Anal 19: 1467 -1476.

\section{How to cite}

SIQUEIRA RG, LOPES DV, SOUZA JJLL, SCHAEFER CEGR, SOUZA CD, OLIVEIRA FSD \& FERNANDES FILHO EI. 2021. Acid sulfate soils from Antarctica: genesis and properties along a climatic gradient. An Acad Bras Cienc 94: e20210625. DOI 10.1590/0001-3765202120210625.

Manuscript received on April 21, 2021;

accepted for publication on August 30, 2021

\section{RAFAEL G. SIQUEIRA ${ }^{1}$}

https://orcid.org/0000-0003-2779-136X

\section{DAVI V. LOPES}

https://orcid.org/0000-0003-3336-7397

\section{JOSÉ JOÃO L.L. DE SOUZA}

https://orcid.org/0000-0003-4670-6626

\section{CARLOS ERNESTO G.R. SCHAEFER}

https://orcid.org/0000-0001-7060-1598

\section{CAROLINE D. SOUZA ${ }^{3}$}

https://orcid.org/0000-0001-5055-3963

\section{FÁBIO S. DE OLIVEIRA 4}

https://orcid.org/0000-0002-1450-7609

\section{ELPÍDIO INÁCIO FERNANDES FILHO'}

https://orcid.org/0000-0003-2440-8329 
${ }^{1}$ Universidade Federal de Viçosa, Departamento

de Solos, Av. PH Rolfs, s/n, Campus Universitário,

36570-000 Viçosa, MG, Brazil

${ }^{2}$ Universidade Federal do Rio Grande do Norte, Departamento

de Geografia, Centro de Ensino Superior do Seridó, Rua

Joaquim Gregório, s/n, Penedo, 59300-000 Caicó, RN, Brazil

${ }^{3}$ Instituto Federal de Minas Gerais, Campus Ouro

Preto, Rua Pandiá Calógeras, 898, Bauxita, Morro

do Cruzeiro, 35400-000 Ouro Preto, MG, Brazil

${ }^{4}$ Universidade Federal de Minas Gerais, Departamento

de Geografia, Av. Antônio Carlos, 6627, Pampulha,

31270-901 Belo Horizonte, MG, Brazil

Correspondence to: Rafael Gomes Siqueira

E-mail: rafael.geo.siqueira@gmail.com

\section{Author Contributions}

The authors Rafael G. Siqueira and Daví V. Lopes designed the study, execution of the research, interpreted the results and wrote the first version of the manuscript. Rafael G. Siqueira processed the data with input from José J.L.L. Souza. The authors José J.L.L. Souza and Caroline D. Souza also helped writing, discussing and revising it. Carlos E.G.R. Schaefer, Elpídio I. Fernandes-Filho and Fabio S. Oliveira supervised the research, helped to translate the manuscript, contributed to the discussion and to the text review.

\section{(c) BY}

